\title{
Effect of Regional Government Characteristics of Financial Performance
}

\author{
Sari Rusmita ${ }^{1}$ \\ ${ }^{1}$ Departement Akuntansi, Fakultas Ekonomi dan Bisnis Universitas Tanjungpura, Indonesia \\ Correspondence: Sari Rusmita, Departement Akuntansi, Fakultas Ekonomi dan Bisnis Universitas Tanjungpura, \\ Indonesia. E-mail: sarirusmita99@gmail.com
}

Received: December 15, 2019

Accepted: January 7, 2020

Online Published: January 15, 2020

doi:10.20849/iref.v3i2.703

URL: https://doi.org/10.20849/iref.v3i2.703

\begin{abstract}
This study aims to determine the effect of regional government characteristics on the financial performance of district / city regional governments in West Kalimantan. This research uses multiple regression. The dependent variable used is the regional financial performance which is proxied from the level of efficiency while the independent variables used are total assets, regional expenditure, DAU, PAD, and leverage as indicators of local government characteristics. The findings of this study indicate that regional spending and dependency of district / city regional governments in West Kalimantan on central government have an influence on the financial performance of district / city governments in West Kalimantan, while government size, prosperity and leverage have no influence on the financial performance of district governments / city in West Kalimantan.
\end{abstract}

Keywords: financial performance, total assets, regional expenditures, DAU, PAD, leverage

\section{Introduction}

The crisis that occurred in 1996-1997 prompted the delegation of part of the authority for financial management from the central government to regional governments, which is usually called the autonomy authority. It is intended that local governments are able to be independent in carrying out development and provide greater flexibility to local governments in carrying out regional development, as well as in financing development and services on the basis of the financial capacity of the local government itself. In addition to this, local governments want to provide services that are more oriented to community satisfaction and the needs and desires of the people regarding the performance of local governments increasingly large and critical, especially since the reform era that gave birth to the decree of the MPR namely TAP MPR number XV / MPR / 1998 concerning the implementation of regional autonomy, regulation, distribution and utilization of equitable national resources as well as central and regional financial balances within the framework of the Republic of Indonesia.

In addition to giving autonomy authority to the central government, the central government is also required to provide a report on the implementation of the regional government (LPPD) to the central government, as a form of evaluation and monitoring of the central government to the regional government in carrying out the autonomy authority. The implementation of the autonomy authority covers compulsory and optional affairs. Obligatory affairs are very basic matters relating to the basic rights and services of citizens. While the choice of affairs is a matter that actually exists in the region and has the potential to improve the welfare of the community, in accordance with the conditions, uniqueness and superior potential of the region (PP No.3 / 2007). District / city government LPPDs are highly dependent on the functions that are their responsibility and the characteristics of each local government (Mustikarini and Fitriasari, 2012).

Implementation of local government needs to be evaluated, as a measurement of the performance and success of local governments in carrying out regional development. According to Chaw, et al (2001) in Sumarjo (2010) performance measurement is an important component because it will provide feedback on plans that have been implemented.

The current phenomenon in Indonesia shows that the people's response to the implementation of regional autonomy is very high so that the regional government is demanded to do good governance and the community is pushing the government to have a more effective and efficient performance from year to year. This shows the existence of public demands for transparency in the management of government finances. 
Through regional autonomy, people expect the creation of efficiency and effectiveness in the management of regional resources, the quality of public services and the welfare of the people increase, as well as civilizing and creating space for people to help in the development process. The implementation of regional autonomy in Indonesia has been running for almost two decades, but the implementation of regional autonomy policy is still not running optimally, this can be seen from the unequal welfare of the people and many gaps between regions. Performance measurement is one way to create good governance (Halacmi, 2005). According to Kusuma (2017) the financial performance of local governments is not only a form of control, but also helps all users of local government financial reports including the public to be able to evaluate the performance of local governments. Regional autonomy that is not yet optimal in local government financial performance is a problem that must be resolved immediately. Performance has even declined compared to before autonomy (Sunardi, 2016). Governance in local governments in Indonesia has not shown a better direction, as evidenced by the still many cases of corruption and efforts to reform the bureaucracy so that this becomes a problem in the implementation of regional autonomy. Transparency and accountability of local government financial performance are demanded to be in the public spotlight (Aziz, 2014).

Poerwadarminta (2006) and Suhardjanto and Yulianingtyas (2010) suggested that the characteristics of local government are special characteristics inherent in local government, marking a region, and differentiating it from other regions. Purba (2006), Rustiono (2008) and Ahmad (2011) in their research linking the characteristics of local government with macroeconomic performance. Patrick (2007) in his study explained the characteristics of local government can be seen with two components, namely organizational structure and external environment. Hasibuan (2009) in Sumarjo (2010) found that there is an influence of company characteristics on a company's performance. This finding can be applied to the public sector, where regional characteristics can be a tool to measure the performance of local government. Differences in characteristics between regions are assumed to affect the financial performance of local governments.

Sumarjo (2010) examined the characteristics of local governments by using the size of the local government which is proxied by total assets, wealth proxied by Regional Original Revenue (PAD), legislative size which is proxied by the total number of DPRD members, the leverage proxied with debt to equity and intergovernmental revenue proxied by a comparison between the total amount of balance funds with the total amount of income as an independent variable.

Size (size) of an area if it has a larger size, the performance is increasingly inefficient because of the large size of the area which is proxied by the total assets will make greater regional expenditure. Research conducted by Shafira (2018), Masdiantini and Erawati (2016), Aziz (2014), Mustikarini and Fitriasari (2012), Kusumawardani (2012) and Sumarjo (2010) show that the size of the local government has a positive effect on financial performance local government. These results are not in line with research conducted by Kusuma (2017), Noviyanti and Kiswanto (2016), Marfiana and Kurniasih (2013) and Nandhya (2013) show that the size of the regional government has no effect on the financial performance of local governments.

Efficiently, the greater total regional expenditure owned by a region can make its performance more inefficient because the expenditure of regional expenditure used will be more and more. However, according to Noviyanti and Kiswanto (2016), the amount of regional expenditure issued by the regional government can make it easier for the regional government to carry out the development program that has been designed in its area. The research is supported by the results of research by Mustikarini and Fitriasari (2012), Marfiana and Kurniasih (2013), Aziz (2014), Kusuma (2017), and Shafira (2018) which show that regional spending has a positive effect on the financial performance of local governments while research conducted by Mustikarini and Fitriasari (2012), Sudarsana (2013), Meilina et al. (2016) and Suryaningsih and Sisdyani (2016) show that regional spending does not affect the financial performance of local governments.

The General Allocation Fund (DAU) is a transfer fund from the central government to regional governments with the aim of meeting the needs of the region. So that shows that the DAU received by local governments depends on the central government will show increasingly strong local governments depend on the central government to meet the needs of their regions. Research Noviyanti and Kiswanto (2016), Elychia (2014), Aziz (2014), Marfiana and Kurniasih (2013), Mustikarini and Fitriasari (2012), Julitawati, et al (2012), Ahmad (2011), Indararti (2011), Sumarjo (2010) and Virgasari (2009) show that the level of dependency on the central government affects the financial performance of local governments, the results of this study are not in line with the research of Mirna (2012), Sudarsana (2013), Nur (2014), Suryaningsih and Sisdyani (2016), Meilina et al (2016), Masdiantini and Erawati (2016), Kusuma (2017), and Shafira (2018) state that the level of dependency on the central government has no effect on the financial performance of local governments. 
Research conducted by Virgasari (2009), Lin et al. (2010), Indrarti (2011), Mustikarini and Fitriasari (2012), Surepno (2013), Sudarsana (2013) and Kusuma (2017) show that prosperity influences financial performance while Shafira's research results (2018), Masdiantini and Erawati (2016) ), Suryaningsih and Sisdyani (2016), Marfiana and Kurniasih (2013), Kusumawardani (2012), Sumarjo (2010) prosperity has no effect on the financial performance of local governments.

This study replicates the research of Shafira (2018) who in his research empirically tested the influence of local government characteristics on financial performance in Indonesia, while this research was conducted in the province of West Kalimantan. In an effort to improve the efficiency and effectiveness of the implementation of regional autonomy, which focuses on districts / cities in the province of West Kalimantan. The ability of local governments to manage their finances can be seen in the regional budget (APBD) which shows the ability of local governments to finance all development activities.

The characteristics of the regional government used in this study are the size of the local government, the prosperity of the local government, the level of dependency on the central government and regional spending. This research is slightly different from the replicated research because this study adds leverage as a characteristic of local government. Several previous studies have made leverage as one of the characteristics of local government. Sumarjo (2010) in his research found that leverage affects the performance of local government. The results are different from Sesotyaningtyas (2012), Kusumawardani (2012), Ayuningsih (2016) and Kusuma (2017) research which found no leverage effect on local government financial performance. The results of previous studies still show inconsistencies, this study will discuss the effect of local government characteristics on the financial performance of local governments, which in this study the District / City in West Kalimantan Province will be the object of this study.

\section{Method}

The form of this research is descriptive. The data used in this study is panel data, from 2014-2016 (3 years) in 12 districts and 2 cities in West Kalimantan Province. The variable in this study is the local financial performance which is proxied from the level of efficiency as the dependent variable while the independent variable is the characteristics of the local government which consists of the size of the regional government, Regional Expenditure, Dependency Level, Wealth and leverage. The research data is secondary data, obtained from the website of the Indonesian Statistics Agency (BPS). Data analysis techniques used to see the effect of the size (size) of local governments, Regional Expenditures, Dependency, Wealth and leverage on regional financial performance in West Kalimantan Province are multiple linear regression analysis, while the regression equation is as follows:

$$
\mathrm{Y}=\alpha+\beta 1 \mathrm{X} 1+\beta 2 \mathrm{X} 2+\beta 3 \mathrm{X} 3+\beta 4 \mathrm{X} 4+\beta 5 \mathrm{X} 5+\mathrm{e}
$$

Where:

$\begin{array}{ll}\mathrm{Y} & : \text { Financial Performance of Local Government } \\ \alpha & : \text { constant } \\ \beta 1, \beta 2, \beta 3, \beta 4, \beta 5 & : \text { coefficients of the independent variables } \\ \mathrm{X} 1 & : \text { government size } \\ \mathrm{X} 2 & : \text { regional expenditure } \\ \mathrm{X} 3 & : \text { the level of dependence on the center } \\ \mathrm{X} 4 & : \text { prosperity of the local government } \\ \mathrm{X} 5 & : \text { Leverage } \\ \mathrm{e} & : \text { error term }\end{array}$

\section{Results}

The model in this study shows there are no problems of normality, multicollinearity, or autocorrelation. This is known because before testing the hypothesis, this study first performed a classic assumption test to find out the normal distribution of data in the study. Test the coefficient of determination seen from the Adjusted R2 value of $98.18 \%$ means it indicates that the independent variables used in this study consisting of total assets, regional expenditure, DAU, PAD, and leverage are able to explain the dependent variable of local government financial performance of $98,18 \%$. While the remaining $1.82 \%$ is explained by other variables outside the independent variables used in this study. While the simultaneous significance test ( $F$ statistical test) obtained a significance value of 0.015 . The significance value is $<0.05$, this result indicates that the regression model is feasible to 
predict the dependent variable.

Furthermore, the results of data processing of the dependent variable are the financial performance of local governments which are proxied from the level of efficiency with the independent variable, namely the characteristics of the local government seen from five indicators which are then translated as an independent variable in this study, namely the size of the government proxy for total assets, expenditure regions, as seen from the realization of regional expenditure, DAU which proxies the level of dependence of the regional government on the central government, prosperity which is proxied from the PAD and the level of leverage that is proxied from the DER owned by the regional government, then the equation estimation model is obtained as follows:

$$
\mathrm{Y}=210.45+25.88 \mathrm{X} 1-623.06 \mathrm{X} 2+677.09 \mathrm{X} 3-81.60 \mathrm{X} 4-4.03 \mathrm{X} 5+\mathrm{e}
$$

A constant value of 210.45 means that if the independent variable is government size (X1), regional expenditure (X2), the level of dependence on the center (X3), prosperity of the local government (X4), and leverage (X5) equal to zero, then the value local government performance $(\mathrm{Y})$ of 210.45. $\beta 1=25.88$ means that if the size of local government increases, the variable performance of local government finances will increase. $\beta 2=-623.06$ means that if regional expenditure increases, the variable performance of local government finances will decrease. $\beta 3=677.09$; means that if the level of dependence on the center increases, then the performance variable will increase. $\beta 4=-81.60$ means that if prosperity increases, then the variable performance of local government finances will decrease. $\beta 5=-4.03$ means that if leverage increases, the regional government performance variable will decrease.

Furthermore, to determine the effect of the independent variable on the dependent variable in this study, a hypothesis test is conducted and the results can be as seen in Table 1 below.

Table 1. Hypothesis Test Results

\begin{tabular}{lcc}
\hline Government Size => Financial Performance of Local Government & Sig & Hypothesis Decision \\
\hline Regional Expenditures => Local Government Financial Performance & 0,026 & Rejected \\
\hline $\begin{array}{l}\text { Dependence on the Central Government => Financial Performance of } \\
\text { Local Governmen }\end{array}$ & 0,026 & Received \\
\hline $\begin{array}{l}\text { Regional Government Independence }=>\text { Financial Performance of } \\
\text { Regional Government }\end{array}$ & 0,136 & Rejected \\
\hline Leverage => Local Government Financial Performance & 0,427 & Rejected \\
\hline
\end{tabular}

Source: Processed Results, 2019

\section{Discussion}

Table 1 shows that from the five hypotheses there are two hypotheses that can be accepted because the significance value is less than 0.05 . Hypothesis 1 which states that the size of the government has an influence on the financial performance of local governments, is rejected. This means that the size of the government in the regencies / cities in West Kalimantan which is proxied from the total assets owned by the regional government does not have an influence on the financial performance achieved by the local government. The results of this study are in line with the results of Shafira (2018), Marfiana and Kurniasih (2013), Nandhya (2013), Talebria et. al (2010) and different from the research findings of Kusumawardani (2012), Sumardjo (2010), Mustikarini and Fitriasari (2012). This indicates that the role of total assets in improving the financial performance of local governments in West Kalimantan Regency / City has not been able to function as it should.

Hypothesis 2 which states that regional spending has an influence on the financial performance of local governments, is acceptable. This can be seen from the significance value smaller than 0.05 which is 0.026 . The results of this study are not in line with research conducted by Mustikarini (2012), Suryaningsih and Sisdyani (2016), Purba (2006) and Rustiono (2008). But it is the same with research conducted by Shafira (2018), Marfiana and Kurniasih (2013). This shows that the regional government in West Kalimantan has realized and used the regional government budget well and this is also an indicator of success and improvement in the performance of the local government towards a better direction. Local governments with large total expenditure should be able to provide good performance. Because regional expenditure both routine and capital expenditure 
and infrastructure can improve the performance of local governments to the community. Regional governments are certainly required to be able to manage expenditures that can improve their performance to the public.

In addition, the other independent variable, namely the dependence of the local government on the central government which in this study proxies from general allocation funds (DAU) shows that it has an influence on the financial performance of local governments, this is indicated by the results of testing the third hypothesis which shows the value of sig. smaller than 0.05 . So it can be concluded that the dependence of local governments on the central government has an influence. The results of this study are in line with Mustikarini and Fitriasari (2012), Sumarjo (2010), Marfiana and Kurniasih (2013), Rahim (2008), Sumarjo (2010), Ahmad (2011), Suryaningsih and Sisdyani (2016), Indararti (2011), Virgasari (2009) but not in line with Shafira (2018), Mirna (2012), Nur (2014), Masdiantini and Erawati (2016). This influence indicates that funds from the center have an influence on the financial performance of local governments that are used to meet regional needs, and the use of these central funds is allocated more to routine expenditure compared to capital expenditure. The regency / city regional government in West Kalimantan on average still has a relatively high level of dependence on the central government, this is not in line with the objectives of regional autonomy so we can say the objectives of regional autonomy have not been realized.

Hypothesis 4, which looks at the influence of local government proxies from PAD funds on the financial performance of local governments shows that the hypothesis is rejected, as well as hypothesis 5 , which states that there is an influence between the proxy of DER leverage on government financial performance. Hypotheses 4 and 5 are rejected, because the sig. from the hypothesis test shows greater than 0.05 , respectively 0.136 and 0.427. The results of this study are in line with research by Marfiana (2013), Sumarjo (2010), Shafira (2018), Kusumawardani (2012), Marfiana and Kurniasih (2013), Masdiantini and Erawati (2016) and contrary to research by Mustikarini and Fitriasari (2012), Lin et. al (2010), Surepno (2013), Indararti (2011), Virgasari (2009). This indicates that PAD does not have an optimal role in improving the financial performance of regional governments, this is because local governments are still dependent on funding from central funds, especially from general allocation funds (DAU), as stated by Hadi, et.al. (2009) in his research.

\section{Conclusion}

The results of hypothesis testing in this study indicate that regional spending and dependency of district / city local governments in West Kalimantan on central government have an influence on the financial performance of district / city governments in West Kalimantan, while government size, prosperity and leverage have no influence on government financial performance district / city areas in West Kalimantan. This shows that the financial performance of local governments in districts / cities in West Kalimantan tends to be less independent and less efficient so that it is hoped that in the future the regional government can conduct evaluations in order to improve regional financial performance. Local governments must make better efforts to increase PAD in an effort to improve the welfare of the community.

Local governments with large assets and wealth (PAD) should be able to provide good performance. Because prosperity with large assets and wealth certainly has greater pressure from the community, to be able to manage and use the resources of the local government in order to improve performance. If the regional government with large assets and assets but the efficiency performance is still considered poor, the local government must introspect and make improvements in the future. Because logically the local government with large assets and wealth certainly has greater pressure from the community to be better in managing and using all of their resources for performance improvement.

\section{Acknowledgements}

I thank the Faculty of Economics and Business, Tanjungpura University in particular the accounting department for providing opportunities, facilities and support in completing this article.

\section{References}

Abdullah Syukriy. (2006). Studi atas belanja modal pada Anggaran Pemerintah Daerah dalam Hubungannya dengan belanja Pemerintahan dan Sumber Pendapatan. Jurnal Akuntansi Pemerintahan, 2(2).

Armaja, Ridwan Ibrahim dan Aliamin. (2015). Pengaruh Kekayaan Daerah, Dana Perimbangan dan Belanja Daerah Terhadap Kinerja Keuangan. Jurnal Perspektif Ekonomi Darussalam, 3.

Ayuningsih, Diyah. (2016). Pengaruh Size, Wealth, Leverage, Belanja Daerah Dan Intergovernmental Revenue Terhadap Kinerja Keuangan Pemerintah Daerah Di Jawa Tengah. Skripsi. Jurusan Akuntansi Syariah Fakultas Ekonomi Dan Bisnis Islam Institut Agama Islam Negeri Surakarta. 
Aziz, Asmaul. (2014). Pengaruh Karakteristik Pemerintah daerah Terhadap Kinerja Keuangan Pemerintah Daerah ( Studi Pada Pemerintah Daerah Kabupaten / Kota Di Jawa Timur). Jurnal Akuntansi, XI(1).

Bastian, Indra. (2006). Akuntansi Sektor Publik Suatu Pengantar Erlangga, Jakarta.

Ghozali, Imam. (2013). Aplikasi Analisis Multivariate dengan program IMB SPSS 21. Semarang: Badan Penerbit Universitas Diponegoro.

Halachmi, A. (2005). Performance Measurements only one Way of Managing Performance. International Journal of Productivity and Performance Management, 54,502-516.

Harteti,Yuni, \& Darwanis dan Syukriy Abdullah. (2014). Pengaruh Desentralisasi Fiskal dan Belanja Daerah Terhadap Kinerja Keuangan Daerah Pada Kabupaten/Kota di Provinsi Aceh. Jurnal Magister Akuntansi Pascasarjana Universitas Syiah Kuala, 3(3).

Julitawati, E., \& Darwanis, dan Jalaluddin. (2012). Pengaruh Pendapatan Asli Daerah (PAD) dan Dana Perimbangan Terhadap Kinerja Kuangan Pemerintah Kabupaten/Kota di Provinsi Aceh. Jurnal Akuntansi Pascasarjana Universitas Syiah Kuala, 1(1).

Kusuma, Aulia Rizka. (2017). Pengaruh Karakteristik pemerintah daerah terhadap efisiensi kinerja keuangan pemerintah daerah Se Jawa Tmur 20132015). Jurnal Ilmu dan Riset Akuntansi, 6(1).

Kusumawardani, M. (2012). Pengaruh Size, Kemakmuran, Ukuran Legislatif, Leverage Terhadap Kinerja Keuangan Pemerintah Daerah di Indonesia. Accounting Analysis Journal, 1.

Mahsun, M., Sulistyowati, F., \& Purwanugraha, dan H. A. (2006). Akuntansi Sektor Publik. Edisi Pertama. BPFE. Yogyakarta.

Mardiasmo. (2009). Akuntansi Sektor Publik. Andi. Yogyakarta.

Marfiana, N., \& Dan Kurniasih, L. (2013). Pengaruh Karakteristik Pemerintah Daerah dan Hasil pemeriksaan audit BPK Terhadap Kinerja Keuangan Pemerintah Daerah Kabupaten/ kota. Jurnal Sustainable Competitive advantage (SCA), 3(1).

Meilina, Zulia Dwi., Hapsari, Dini Wahjoe dan Dilak, \& vaya Juliana. (2016). Pengaruh Karakteristik Pemerintah Daerah dan Hasil Pemeriksaan BPK Terhadap Kinerja Pemerintah Daerah. e-proceeding of management. $3(3)$.

Nordiawan, D., \& Hertianti, dan A. (2010). Akuntansi Sektor Publik. Edisi Kedua. Salemba Empat. Jakarta.

Noviyanti, N. A. dan Kiswanto. (2016). Pengaruh Karakteristik Pemrintah Daerah TemuanAudit BPK Terhadap Kinerja Keuangan Pemerintah Daerah. Accounting Analysis Journal, 5.

Nugroho, T. R., \& dan Prasetyo, N. E. (2018). Pengaruh karakteristik pemerintah daerah terhadap kinerja keuangan pemerintah daerah kabupaten/kota di Jawa Timur. Jurnal akuntansi dan pendidikan, 7(1).

Patrick, P. A. (2007). The Determinants of organizational innovativeness: The adoption of GASB 34 in Pennsylvania local government. Ph.D. Dissertation, The Pennsylvania State University, From Accounting\& Tax Periodicals.

Peraturan Mentri Dalam Negeri nomor 13 tahun 2006 tentang pedoman pengurusan. Jakarta. Presiden RI.

Peraturan Mentri Dalam Negeri nomor 29 tahun 2002 tentang pedoman pengurusan. Jakarta. Presiden RI.

Peraturan Mentri Dalam Negeri Nomor 59 Tahun 2007 tentang pedoman pengelolaan keuangan daerah. Jakarta.Presiden RI.

Peraturan Pemerintah No 71 Tahun 2010 Tentang Laporan Keuangan Pemerintah Daerah. Jakarta. Presiden RI.

Ramasamy, bala, Darryl Ong dan Matthew C. H. Yeung. Firm Size, Ownership and Performance in The Malaysian Palm Oil Industry. 2005. Asian Academy of Management Journal of Accounting and Finance. Vol 1, 81-104

Sari, Indah Puspa. (2016). Pengaruh ukuran pemerintah daerah, PAD, Leverage, dana perimbangan dan ukuran legislative terhadap kinerja keuangan pemerintah daerah. JOM Fekon, 3(1).

Sesotyaningtyas, Mirna. (2012). Pengaruh Leverage, Ukuran Legislatif, Intergovernmental Revenue Dan Pendapatan Pajak Daerah Terhadap Kinerja Keuangan Pemerintah Daerah. Accounting Analysis Journal, 1(1), Hal. 1-6. https://doi.org/10.15294/aaj.v1i1.711

Setyaningrum, Dyah dan Syafitri, \& Febriyani. (2012). Analisis pengaruh karakteristik pemerintah daerah terhadap tingkat pengungkapan laporan keuangan. Jurnal Akuntansi dan Keuangan Indonesia, 9(2). 
Siregar, Oktarini Khamilah. (2017). Measurement of Regional Financial Performance and Economic Growth: A Lesson from North Sumatra Province, Indonesia. International Journal of Accounting and Financial Reporting, 7(1).

Sudrajat. (2017). Dasar-dasar penelitian ilmiah revisi. Bandung: Pustaka Setia.

Suhardjanto, D., \& Yulianingtyas, dan R. R. (2011). Pengaruh Karakteristik Pemerintah Daerah Terhadap Kepatuhan Pengungkapan Wajib dalam Laporan Keuangan Pemerintah Daerah. Jurnal Akuntansi \& Auditing, $8(1)$.

Sumarjo, H. (2010). Pengaruh karakteristik pemerintah daerah terhadap kinerja keuangan pemerintah daerah (Studi empiris pada pemerintah daerah kabupaten/kota di Indonesia). (Skripsi. Universitas Sebelas Maret Surakarta).

Sunardi. (2016). Analisis Pengukuran Kinerja Keuangan.

Suranta, Sri dan Siregar, \& Oktavian. (2015). Pengaruh Karakteristik Pemerintah Daerah Terhadap Kepatuhan Pengungkapan Investasi pemerintah daerah (Studi pada Pemerintah Kabupaten/Kota di Pulau Jawa dan Sumatera). Jurnal Akuntansi, 3(1).

Surepno. (2013). Pengaruh return on equity (ROE), ukuran (Size) dan kemakmuran Wealth) pemerintah daerah terhadap kinerja keuangan pemerintah daerah di Indonesia. (Skripsi). Semarang: Fakultas Ekonomi Universitas Negeri Semarang.

Suryaningsih, Ni Made dan Sisdyani, \& Eka Ardhani. (2016). Pengaruh Karakteristik Pemerintah daerah dan Opini Audit BPK terhadap kinerja keuangan pemerintah daerah (Kabupaten/ kota indonesia tahun 2013). Jurnal Akuntansi, 15(2).

Undang Undang Nomor 32 Tahun 2004 tentang pemerintah daerah.

Undang Undang Nomor 33 Tahun 2004 tentang perimbangan keuangan antara pemerintah pusat dengan pemerintah daerah.

Weill, Laurent. (2003). Leverage and corporate performance: a frontier efficiency analysis on European countries. Working Paper, Working Paper Series. SSRN May.

\section{Copyrights}

Copyright for this article is retained by the author(s), with first publication rights granted to the journal.

This is an open-access article distributed under the terms and conditions of the Creative Commons Attribution license (http://creativecommons.org/licenses/by/4.0/). 